\title{
Anisotropic larval connectivity and metapopulation structure driven by directional oceanic currents in a marine fish targeted by small-scale fisheries
}

Adrian Munguia-Vega, 1,2凶

Email airdrian@email.arizona.edu

S. Guido Marinone, 3

David A. Paz-Garcia, 4,5

Alfredo Giron-Nava, 6

Tomas Plomozo-Lugo, 7

Ollin Gonzalez-Cuellar, 7

Amy Hudson Weaver, 7

Francisco J. García-Rodriguez, 8

Hector Reyes-Bonilla, 9

1 PANGAS Science Coordination, Comunidad y Biodiversidad A.C., Guaymas, Sonora, Mexico

2 Conservation Genetics Laboratory, School of Natural Resources and the Environment, The University of Arizona, 1064 East Lowell St., Tucson, AZ, 85721 USA

3 Departamento de Oceanografía Física, Centro de Investigación Científica y de Educación Superior de Ensenada, Ensenada, Baja California, Mexico 4 Marine Speciation and Molecular Evolution Laboratory, Department of 
Biological Sciences, Louisiana State University, Baton Rouge, LA, USA

5 Laboratorio de Necton y Ecología de Arrecifes, Centro de Investigaciones Biológicas del Noroeste, Instituto Politécnico Nacional, 195, Col. Playa Palo de Santa Rita Sur, La Paz, Baja California Sur, Mexico

6 Marine Biology Research Division, Scripps Institution of Oceanography, University of California, La Jolla, San Diego, CA, USA

7 Sociedad de Historia Natural Niparajá A.C, La Paz, Baja California Sur, Mexico

8 Instituto Politécnico Nacional, Centro Interdisciplinario de Ciencias Marinas, La Paz, Baja California Sur, Mexico

9 Laboratorio de Sistemas Arrecifales, Universidad Autónoma de Baja California Sur, La Paz, Baja California Sur, Mexico

Received: 5 August 2017 / Accepted: 13 November 2017

\section{Abstract}

The dispersal during the planktonic larval period is a key feature to understand the metapopulation structure of marine fishes, and is commonly described by four general models: (1) lack of population structure due to extensive larval dispersal; (2) isolation by geographic distance, where larval connectivity decreases with increasing distance between sites in all directions (isotropy); (3) population structure without any clear geographic trend (chaotic); and (4) population structure explained by seascape approaches that explicitly incorporate the spatial and temporal variations in the direction and strength of oceanic currents via oceanographic modeling. We tested the four models in the Pacific red snapper Lutjanus peru, a key commercial species in the Gulf of California (GC), Mexico. We genotyped 15 microsatellite loci in 225 samples collected during 2015-2016 from 8 sites, and contrasted the observed empirical genetic patterns against predictions from each model. We found low but significant levels of 
population structure among sites. Only the seascape approach was able to significantly explain levels of genetic structure and diversity, but exclusively within spring and summer, suggesting that this period represents the spawning season for L. peru. We showed that in the GC, the strong asymmetry in the oceanic currents causes larval connectivity to show different values when measured in distinct directions (anisotropy). Management tools, including marine reserves, could be more effective if placed upstream of the predominant flow. Managers should consider that oceanographic distances describing the direction and intensity of currents during the spawning period are significant predictors of larval connectivity between sites, as opposed to geographic distances.

\section{AQ1}

AQ2

Responsible Editor: O. Puebla.

Reviewed by M. Soares and an undisclosed expert.

Electronic supplementary material

The online version of this article (https://doi.org/10.1007/s00227-017-3267-x) contains supplementary material, which is available to authorized users.

\section{Introduction}

Many species of marine fish have a complex life history that starts with a planktonic larval stage that can last few days up to several months, and during this time, oceanic currents can transport the planktonic larvae before settling as relatively sedentary adults (Luiz et al. 2013; Green et al. 2015). Larval dispersal is a key factor that defines how marine populations are structured, and is influenced by several life history traits including spawning time and location, length of the spawning period and planktonic larval duration (PLD), among others (Cowen and Sponaugle 2009). An understanding of how larval connectivity influence source-sink metapopulation dynamics and local larval replenishment could help to increase the effectiveness of marine spatial management tools (Sale et al. 2006). For example, during the design of 
networks of marine, reserves or no-take zones patterns of larval dispersal for focal species could inform about optimal reserve location and spacing (Munguia-Vega et al. 2014; Green et al. 2015; Dubois et al. 2016).

Genetic analyses are a useful tool to infer the metapopulation dynamics of diverse marine species (Selkoe et al. 2014; Pascual et al. 2017). Three main population genetic scenarios or models have been proposed to explain how populations of marine organisms with a planktonic larval stage are structured, and each model is associated with characteristic patterns of genetic differentiation present between sites. The first model is based on the frequent observation that marine species show very low levels or a complete absence of population structure, indicative of panmixia over large geographical scales (Rocha-Olivares and Sandoval-Castillo 2003; Hedgecock et al. 2007). This pattern has been interpreted as the result of extensive larval dispersal and low genetic drift associated with large effective population sizes (Hedgecock et al. 2007).

The second model suggests that the probability of larval connectivity uniformly decreases with increasing distance between locations (Almany et al. 2009; Green et al. 2015), and is generally represented by an isotropic dispersal kernel (i.e., has the same value when measured in different directions) (Cowen et al. 2000; Jones et al. 2005). This pattern of isolation by geographic distance has been described by comparing allele frequencies between sites via $F_{\mathrm{ST}}$ values in species with direct development and across a wide range of PLDs (Teske et al. 2015, 2016; Almany et al. 2017). The practical application of the isolation by geographic distance model is recommendations about spacing in networks of marine reserves (e.g., between 15 and $100 \mathrm{~km}$ ) to ensure that the mutual replenishment of larvae between reserves has demographic impacts (i.e., demographic connectivity) which increase the probability of network persistence (Sala et al. 2002; Almany et al. 2009; Green et al. 2015).

The third model, known as "chaotic genetic patchiness", describes significant population structure among sites without any clear geographic or temporal trend, and is generally attributed to high variability in individual reproductive success that leads to distinctive patterns of localized recruitment (Johnson and 
Black 1982, 1984; Hedgecock and Pudovkin 2011). Recent studies have suggested that this pattern can be explained by pulses of settlement of genetically related larvae, also known as collective dispersal, that remain together during their larval stage (Iacchei et al. 2013; Ottmann et al. 2016).

However, other causal factors of chaotic genetic patchiness have also been proposed, including diversifying selection, temporal shifts in local population dynamics, strong genetic drift, and other seascape drivers including habitat extension (Eldon et al. 2016; Selkoe et al. 2010, 2014). A recent methodology, dubbed seascape genetics, suggests that apparent chaotic genetic patterns could be explained by explicitly considering ecological and oceanographic variables in a spatial and temporal context (Galindo et al. 2006; Selkoe et al. 2016). One of the most promising methods in seascape genetics tries to describe the underlying mechanism driving patterns of export and import of larvae among sites and levels of local larval retention within sites by predicting oceanic currents with computer models (Metaxas and Saunders 2009; Marinone 2012; Treml et al. 2012). Oceanographic models are spatially-explicit numerical models that simulate dispersal of particles (analogous to larvae) by oceanic currents based on a precise description of topography, bathymetry, temperature, salinity, tides, wind, fresh water influx, etc., while also incorporating information about spawning time and PLD (Metaxas and Saunders 2009).

The Pacific red snapper Lutjanus peru (Nichols and Murphy 1922) is a demersal fish species abundant near the coast in waters up to $91 \mathrm{~m}$ depth, associated with rock and coral reefs, and distributed from California US to Peru (Rocha-Olivares and Sandoval-Castillo 2003). The species is one of the most important commercial marine fishes both in terms of value and total catch for small-scale fisheries in the Pacific coast of Mexico (Zarate-Becerra et al. 2014), including the Gulf of California (GC) (Diaz-Uribe et al. 2004). Landings for L. peru in the Southwestern GC (SWGC, Fig. 1a) during the period 1998-2008 averaged 598 tons worth 1.13 million USD, which represents $66 \%$ of the total catch for the entire GC (Erisman et al. 2010). For the period 2011-2013, an average of at least $~ 330$ tons was landed in the SWGC according to official records (Niparaja A.C. and Pronatura Noroeste A.C. 2014). 


\section{Fig. 1}

a Study area in the Southwest of the Gulf of California showing main islands, marine reserves, and bathymetry. Note that the sizes of the marine reserves are not shown to scale. b Location of 20 spatial units of analyses used during the oceanographic simulations to calculate connectivity matrices based on the dispersal of virtual larvae that were transported by currents from the 20 release sites indicated by stars. The eight release sites where genetic samples of Lutjanus peru were also obtained are indicated by a star within a circle

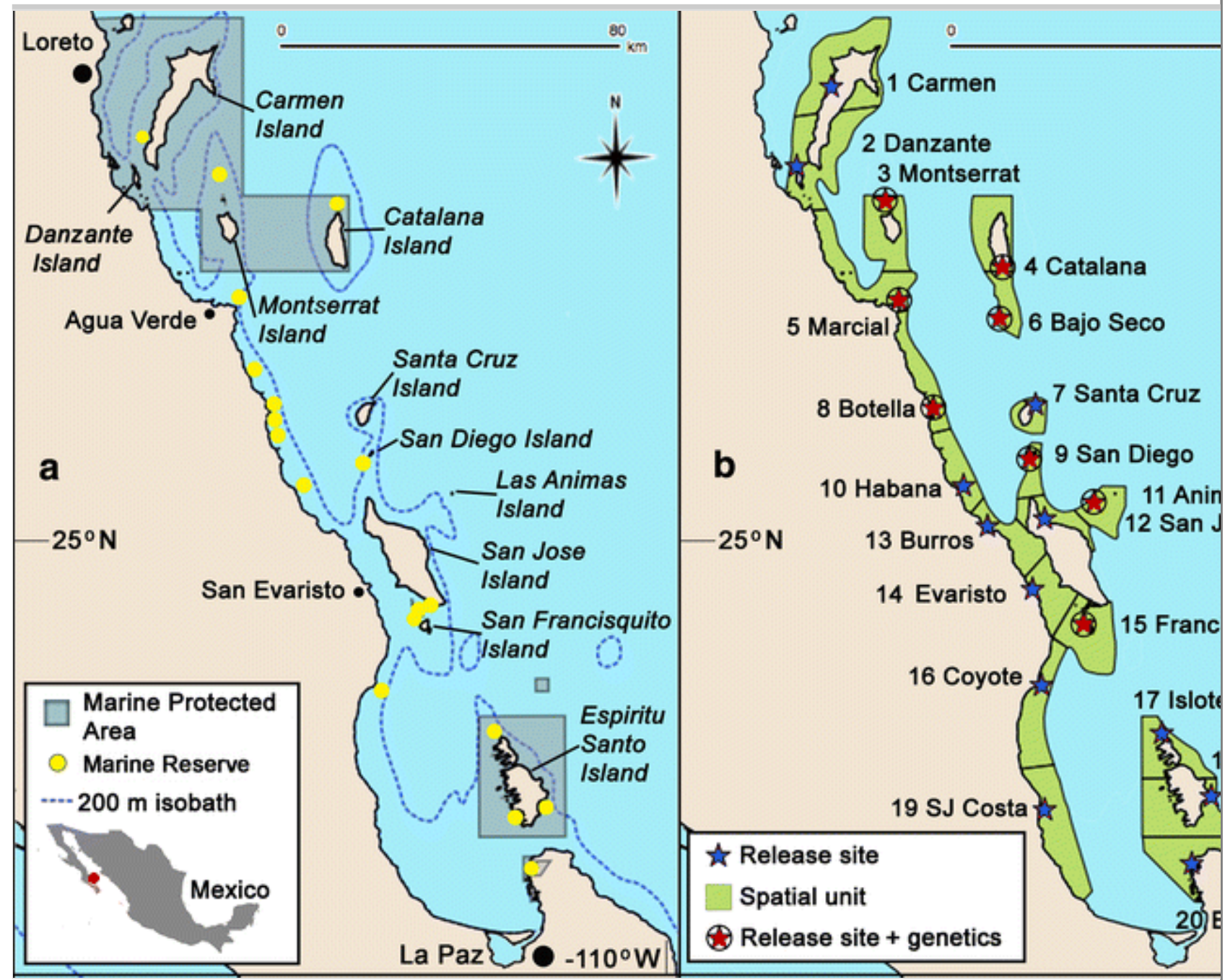

The GC is a narrow $(100-150 \mathrm{~km})$ semi-enclosed sea and a fitting area to study the impact of oceanic currents on the population structure of marine fishes with planktonic larvae. In the GC, multiple seasonal oceanic gyres present within each of the main deep $(1-3 \mathrm{~km})$ basins shift direction at the 
beginning of the spring (March) and fall (October) seasons (Marinone et al. 2011; Marinone 2012). These gyres create a unique model system, where strongly asymmetric oceanic currents define a metapopulation structure, where upstream larval sources export larvae towards specific downstream locations, according to the spawning time and the direction of the predominant flow (Soria et al. 2012; Beldade et al. 2014; Munguia-Vega et al. 2015; Lodeiros et al. 2016).

We used microsatellite genotypes to measure levels of genetic differentiation between populations and genetic diversity within populations of $L$. peru from the SWGC. We tested in which of three scenarios our results fit, hypothesizing that population genetic structure of L. peru follows either (a) a panmictic pattern, (b) isolation by distance, or (c) chaotic genetic patchiness. Then, we used a seascape genetic approach to calculate seasonal oceanographic distances among locations in the SWGC and compared its ability to explain observed levels of population structure against the other traditional models outlined above.

\section{Methods}

\section{Study area}

Our study area in the SWGC covers $\sim 200 \mathrm{~km}$ along the Southeast portion of the Baja California Peninsula, Mexico, between the cities of La Paz and Loreto (Fig. 1a). The area includes nine large islands, dozens of islets and three marine protected areas (MPAs, here defined as geographical areas under some kind management), namely (from north to south): Bahia de Loreto National Park, Espiritu Santo National Park and Balandra Flora and Fauna protection area (Fig. 1a). Eighteen marine reserves (defined here as no-take zones that are fully protected from all extractive and destructive activities, including fishing) are present in the region, including 7 marine reserves within core zones of the three MPAs administered by the National Commission of Protected Areas (CONANP) and 11 sites recognized as fishery refugia administered by the National Commission of fisheries (CONAPESCA).

\section{Oceanographic model}


The study area was divided into 20 large spatial units or polygons to calculate connectivity matrices (Fig. 1b). Spatial units were designed combining data about the coastline (http://www.ngdc.noaa.gov/mgg/shorelines /shorelines.html), political boundaries including MPAs in Mexico (www.conanp.gob.mx), and the domain was restricted by the $200 \mathrm{~m}$ isobath that is often used as a proxy for the edge of the continental shelf, where there is a dramatic ecotone between shallow and deep water habitats (Spalding et al. 2007).

A literature review about the spawning time of L. peru in the GC showed contradictory results among studies that suggested different reproductive periods covering the entire year, including spawning from November through April (Zarate-Becerra et al. 2014), April to June (Diaz-Uribe et al. 2004), May to September (Erisman et al. 2010), and June to July and September to October (Barbosa-Ortega et al. 2015). We predicted that, if L. peru larvae are transported during particular seasons after spawning, then patterns of genetic diversity and structure will show a better fit with the oceanographic connectivity during the seasons, where most larvae gets transported by currents, as opposed to seasons, where no spawning occurs or larvae has already developed into juveniles that are no longer part of the plankton. Given the uncertainty in the spawning time of the species, we modeled the four different seasons (winter, spring, summer, and fall). The larval dispersal simulations included the months of January and February (winter), April and May (spring), July and August (summer), and October and November (fall). We excluded the months of transition between seasons, because we were interested in capturing the main oceanographic patterns typical of each season. For each month, the starting trajectories were for both spring and neap tides (see Online Resource 1), since in the GC, they represent the full range of dispersal scenarios (i.e., maximum and minimum, respectively), and any other calendar day within a particular month will be intermediate to these values (Soria et al. 2012). Seasonal oceanographic regimes in the GC are strongly consistent across years, and the most significant inter-annual variability is represented by ENSO events (Marinone 2003; Soria et al. 2014). Thus, the year 2015 was arbitrarily chosen as the simulation year, because the model represents the ocean circulation of any typical year, and only the phase of the 
spring-neap cycle is the one that gets shifted from year to year. Due to uncertainty about initial conditions for these models, analysis typically centers on long-term equilibrium (White et al. 2011). Our model converges within 3 years, and in all the analyses, we used the circulation from the fourth year. We seeded 4000 passive particles (or virtual larvae) at each of 20 locations (Fig. 1b) for each release date. Although no published references exist for the PLD of L. peru, a review of 18 species within the genus Lutjanus (Luiz et al. 2013) showed an average PLD of 29.4 days (range 21.75-40 days). We thus tracked the larvae during our simulations for 28 days or 4 weeks.

AQ3

Passive particles were allowed to be advected from an Eulerian velocity field obtained from the baroclinic three-dimensional numerical model HAMSOM developed by Backhaus (1985) and adapted to the GC (Marinone 2003, 2006, 2008). The HAMSOM model results have been validated by several studies where it has successfully reproduced seasonally reversing gyres (Marinone et al. 2008), tides, sea surface and currents (Marinone et al. 2009), the deep circulation around large islands (Marinone 2008) and larval dispersal patterns in other fishes (Munguia-Vega et la. 2014). Briefly, the model domain has a mesh size of $0.833^{\prime} \times 0.833^{\prime}(\sim 1.3 \times \sim 1.5 \mathrm{~km})$ in the horizontal and 12 layers in the vertical with nominal lower levels at 10, 20,30,60,100, 150, 200, 250, $350,600,1000$, and $4000 \mathrm{~m}$. The model equations include fully prognostic temperature and salinity fields, thus allowing time-dependent baroclinic motions. The model is started from rest, and the time step is $300 \mathrm{~s}$. At the mouth of the GC, the forcing is with tides, and with $T, S, u, v$ obtained from GLORYs. At the sea surface climatological heat and fresh water, fluxes are included and the wind field is taken from ftp://podaac.jpl.nasa.gov /ocean_wind/ccmp/L3.0/data/flk/ site every $6 \mathrm{~h}$.

The trajectories were calculated with the advection/diffusion scheme described in Visser (1997) and Proehl et al. (2005) as described in detail previously (Marinone et al. 2008). The Lagrangian trajectories are due to the HAMSOM Eulerian velocity field and a random-walk contribution related to turbulent eddy diffusion processes. The position of the particles is then calculated as 


$$
\begin{gathered}
X(t+\mathrm{d} t)=X(t)+X_{a}(t)+R_{x} \ddot{O}\left(2 A_{\mathrm{h}} \mathrm{d} t / s_{x}^{2}\right) \\
Y(t+\mathrm{d} t)=Y(t)+Y_{a}(t)+R_{y} \ddot{O}\left(2 A_{\mathrm{h}} \mathrm{d} t / s_{y}^{2}\right) \\
Z(t+\mathrm{d} t)=Z(t)+Z_{a}(t)+R_{z} \ddot{O}\left(2 A_{\mathrm{v}} \mathrm{d} t / s_{z}^{2}\right)+\mathrm{d} t \partial A_{\mathrm{v}} / \partial Z
\end{gathered}
$$

where $(X, Y, Z)$ are the particle positions in the zonal, meridional, and vertical directions, respectively, at time $t . X_{\mathrm{a}}, Y_{\mathrm{a}}$, and $Z_{\mathrm{a}}$ are the advective displacements obtained by integrating the velocity field, $V_{\mathrm{a}}=(u, v, w) . A_{\mathrm{h}}$ and $A_{\mathrm{v}}$ are the horizontal and vertical diffusivities, respectively, and are taken from the Eulerian numerical model. The horizontal eddy diffusivity is constant $\left(A_{\mathrm{h}}=100 \mathrm{~m}^{2} \mathrm{~s}^{-1}\right)$. The velocity and the vertical eddy diffusivity at each particle position are calculated by bilinear interpolation of the instantaneous Eulerian velocity and vertical diffusivity fields from the numerical model, which were saved every hour. $R_{x}, R_{y_{2}}$, and $R_{z}$ are random variables with zero mean and variance $\sigma_{x}{ }^{2}, \sigma_{y}{ }^{2}$, and $\sigma_{z}{ }^{2}$, respectively. For uniform distribution between -1 and 1 , the variances are 1/3 (Visser 1997). We assumed that larvae are advected as passive particles and do not migrate vertically downward to deep depths, as supposed in other similar studies (e.g., Watson et al. 2010).

Hourly latitude and longitude data for each modeled particle were imported into MATLAB (Mathworks). To identify the intersection between particles and each spatial unit at the end of the PLD, we used a selection by location function (in-polygon). We generated connectivity matrices calculating the proportion of larvae that settled at each location relative to the total number of larvae released at each site. We constructed matrices averaging for the four larval release dates within each of the four seasons. We calculated local retention as the proportion of larvae released within an area (spatial unit of analysis) that remains within the natal area at the end of the PLD (Burgess et al. 2014). We also calculated Export Probability (EP) as the sum of larval export from sources $i$ into location $j$, and Import Probability (IP) as the sum of larval imports from sources $j$ into location $i$ (Munguia-Vega et al. 2014). Sources are populations in which the net export of larvae is greater than the 
net import, while the reverse are sinks (Cowen and Sponaugle 2009). We identified each location as either source or sink by subtracting IP from EP (i.e., EP - IP), where positive values identify net exporters or sources and negative values correspond to net importers or sinks.

Connectivity matrices for each season were displayed using graph theory and a spatial network approach using the software GEPHI (Bastian et al. 2009), where nodes represent sites and links directional larval dispersal probabilities (Treml et al. 2008, 2012). We calculated four statistics that describe the relationship among elements (i.e., sites or nodes) in complex networks (Newman 2003), including: (1) graph size (the total number of directed links within a graph); (2) in-degree (number of links that enter a node); (3) out-degree (number of links that leave a node); and (4) eigenvector centrality of the directed network (eigenvector of the adjacency matrix) by running 1000 iterations, which gives the contribution of site $i$ to the growth rate of a linear metapopulation model (Watson et al. 2011).

We used the spatial networks describing patterns of larval dispersal for each season according to the oceanographic model to calculate the graph distance (hereafter oceanographic distance) between pairs of sites (nodes) with the software GENETICSTUDIO (Dyer 2009). Graph distance is the length of the minimum topological distance (i.e., shortest geodesic path) between two nodes, calculated conditional to the entire data set of nodes and links, considering the topology of the network and the strength of the connection between nodes (Dyer 2015).

\section{Population genetics}

We collected L. peru tissue samples (fin clips preserved in 70\% ethanol) from 225 individuals from eight localities (Table 1) during 2015 and 2016 with help from small-scale fishers under permit \# 103053993271-5 and PPF/DGOPA-224/16 issued by CONAPESCA. Samples included multiple size classes and cohorts targeted by commercial fisheries ranging from $\sim 28$ to $65 \mathrm{~cm}$ in total length. We extracted genomic DNA with the DNeasy blood and tissue kit (Qiagen). Each individual was amplified at 15 independent hypervariable tetranucleotide microsatellite loci we recently described for $L$. peru: Lupe01, Lupe02, Lupe13, Lupe16, Lupe21, Lupe23, Lupe24, Lupe25, 
Lupe 28, Lupe29, Lupe34, Lupe39, Lupe55, Lupe62, and Lupe63, following published PCR protocols and conditions (Paz-García et al. 2017). Alleles were sized on an ABI PRISM 3730XL DNA sequencer (Applied Biosystems) using GENESCAN ${ }^{\text {TM }} 500$ LIZ as size standard, scored with the software GENEMARKER (Softgenetics), and assigned into bins with the software FLEXIBIN (Amos et al. 2007). We tested for significant deviations from Hardy-Weinberg equilibrium (HWE) and linkage disequilibrium (LD) with the software GENEPOP employing 10,000 dememorization steps, 1000 batches, and 10,000 iterations (Raymond and Rousset 1995). We adjusted $P$ values with a false discovery rate (FDR) method $(\alpha=0.05)$ (Benjamini and Yekutieli 2001). We tested for null alleles, genotyping errors, and large allele drop-out with the software MICROCHECKER (Van Oosterhout et al. 2004).

\section{Table 1}

Genetic diversity in Lutjanus peru measured with 15 microsatellite loci at eight site: Fig. 1 for details), including average and standard error (SE) for sample size (N), numl alleles $(\mathrm{Na})$, number of effective alleles $(\mathrm{Ne})$, allelic richness (AR), observed (Ho expected $(\mathrm{He})$ heterozygosities, private alleles (PA), private allelic richness (PAR) average pairwise relatedness ( $R$, showing $95 \%$ confidence interval)

\begin{tabular}{|c|c|c|c|c|c|c|c|c|c|}
\hline Site & $N$ & $\mathbf{N a}$ & $\mathrm{Ne}$ & $\mathbf{A R}$ & Ho & He & PA & PAR & $R$ \\
\hline \multicolumn{10}{|l|}{$\begin{array}{l}3 \\
\text { Montserrat }\end{array}$} \\
\hline Mean & 23 & 15.800 & 10.407 & 15.8 & 0.722 & 0.858 & 0.133 & 0.29 & $-0 . C$ \\
\hline $\mathrm{SE}$ & & 1.363 & 1.306 & & 0.052 & 0.033 & 0.091 & & $\begin{array}{l}(-0 . \\
-0 . C\end{array}$ \\
\hline \multicolumn{10}{|l|}{4 Catalana } \\
\hline Mean & 28 & 17.600 & 11.854 & 16.81 & 0.822 & 0.904 & 0.467 & 0.55 & $-0 . C$ \\
\hline SE & & 1.486 & 1.107 & & 0.026 & 0.010 & 0.192 & & $\begin{array}{l}(0.00 \\
-0.0\end{array}$ \\
\hline \multicolumn{10}{|l|}{5 Marcial } \\
\hline Mean & 29 & 18.600 & 12.073 & 17.26 & 0.784 & 0.898 & 0.533 & 0.51 & $-0 . C$ \\
\hline SE & & 1.549 & 1.257 & & 0.043 & 0.014 & 0.192 & & $\begin{array}{l}(-0 . \\
-0 . c\end{array}$ \\
\hline 6 Bajo Seco & & & & & & & & & \\
\hline
\end{tabular}




\begin{tabular}{|c|c|c|c|c|c|c|c|c|c|}
\hline Site & $N$ & $\mathbf{N a}$ & $\mathrm{Ne}$ & $\mathbf{A R}$ & Ho & He & PA & PAR & $R$ \\
\hline Mean & 28 & 18.400 & 12.002 & 17.1 & 0.846 & 0.901 & 0.800 & 0.78 & $-0 . c$ \\
\hline SE & & 1.527 & 1.232 & & 0.023 & 0.013 & 0.262 & & $\begin{array}{l}(-0 . \\
-0 . \dot{C}\end{array}$ \\
\hline \multicolumn{10}{|c|}{8 Botella } \\
\hline Mean & 30 & 18.533 & 11.963 & 16.93 & 0.850 & 0.901 & 0.800 & 0.74 & 0.00 \\
\hline SE & & 1.647 & 1.224 & & 0.026 & 0.013 & 0.262 & & $\begin{array}{l}(0.01 \\
-0 . C\end{array}$ \\
\hline \multicolumn{10}{|c|}{9 San Diego } \\
\hline Mean & 32 & 19.933 & 13.003 & 17.79 & 0.859 & 0.910 & 0.800 & 0.75 & $-0 . c$ \\
\hline SE & & 1.599 & 1.219 & & 0.014 & 0.011 & 0.200 & & $\begin{array}{l}(-0 . \\
-0 .\end{array}$ \\
\hline \multicolumn{10}{|c|}{11 Animas } \\
\hline Mean & 23 & 17.467 & 12.066 & 17.47 & 0.829 & 0.905 & 0.133 & 0.26 & $-0 . c$ \\
\hline $\mathrm{SE}$ & & 1.305 & 1.125 & & 0.031 & 0.010 & 0.091 & & $\begin{array}{l}(-0 . \\
-0 .\end{array}$ \\
\hline \multicolumn{10}{|c|}{$\begin{array}{l}15 \\
\text { Francisquito }\end{array}$} \\
\hline Mean & 32 & 19.000 & 12.887 & 17.27 & 0.766 & 0.910 & 0.533 & 0.49 & $-0 . c$ \\
\hline SE & & 1.636 & 1.170 & & 0.060 & 0.011 & 0.165 & & $\begin{array}{l}(-0 . \\
-0 .\end{array}$ \\
\hline \multicolumn{10}{|c|}{ Average } \\
\hline Mean & 28.12 & 18.167 & 12.032 & & 0.810 & 0.898 & & & \\
\hline $\mathrm{SE}$ & 0.326 & 0.531 & 0.419 & & 0.013 & 0.006 & & & \\
\hline
\end{tabular}

\section{Genetic diversity}

We measured genetic diversity within each location by estimating average observed and expected heterozygosities, number of alleles, number of private alleles (alleles that are exclusive to one site), and number of effective alleles (a measure of allelic diversity which takes into consideration differences in sample size among localities) with the software GENALEX (Peakall and 
Smouse 2012). We estimated allelic richness, and private allelic richness via rarefaction with the software HP-RARE (Kalinowski 2005). We estimated pairwise relatedness values between individuals, a measure of the proportion of alleles identical by descent (Queller and Goodnight 1989), and calculated average values within each locality employing 1000 permutations and 1000 bootstraps to estimate $95 \%$ CI with GENALEX.

We predicted that, if larval sources differ genetically, genetic diversity within site $i$ will depend on the number of sources from which larvae are imported into site $i$ (i.e., in-degree) as estimated from to the oceanographic model (Kool et al. 2011). To test if in-degree could explain the levels of genetic diversity found within each site, we performed a linear regression with the software R (R-Core-Team 2017) between the in-degree values for each season and the average number of effective alleles found in each site.

In the presence of local larval retention, the relatedness values among individuals within a site are expected to increase (Christie et al. 2010; Teske et al. 2016). To test if local retention from the oceanographic model predicted genetic relatedness within sites, we performed a linear regression with the $\mathrm{R}$ software between the probability of local retention for each season and the average relatedness found within each site. We also predicted that genetic relatedness within a site could not only depend upon local larval retention but that could be heavily influenced by the net balance between the amount of larvae that is imported and exported into/from a site, respectively. We hypothesized that sites that act like net sinks will have higher levels of relatedness, because they could receive larvae that result from collective dispersal in addition to the presence of self-retention. In contrast, we predicted low level of relatedness at sites that are net sources, where most larvae leave their natal site. We tested this hypothesis with a linear regression in $R$ between the EP and IP values of each site for each season estimated from the oceanographic model and the average value of relatedness within each site.

\section{Genetic structure}

We estimated the statistical power of the 15 genotyped loci to detect low $F_{\text {ST }}$ values (e.g., < 0.01) with the software POWSIM (Ryman and Palm 2006), 
using a Fisher exact test to compare simulations for eight populations, employing observed sample sizes and allele frequencies and 1000 replicates. To investigate the model of panmixia, we performed an Analysis of Molecular Variance (AMOVA) to estimate the amount of genetic variation found within individuals, among individuals and among different locations, and tested for significance with 999 permutations with the software GENODIVE (Meirmans and Van Tienderen 2004). To test the model of chaotic genetic patchiness, we estimated genetic distance between locations with the software GENODIVE employing $F_{\mathrm{ST}}$ and the JostD estimator and searched for any geographical trend. Unlike $F_{\mathrm{ST}}$, JostD is not biased by levels of within population heterozygosity that are typically high for microsatellite loci (Jost 2008). We assessed the significance of pairwise $F_{\mathrm{ST}}$ values with an AMOVA test and 1000 permutations in GENODIVE.

To test the model of isolation by geographic distance, we calculated geographic distances between the sites, where larvae were released in the oceanographic model with the software GENALEX. We performed a Mantel test with 10,000 randomizations between log transformed matrices of both geographic distance and empirical genetic distances (JostD) with the software IBDWS (Jensen et al. 2005).

To test if the oceanographic distances between sites, as estimated from the spatial networks informed by the oceanographic model, could explain observed genetic distances, we performed a Mantel test between log transformed matrices of both oceanographic distances for each season and empirical genetic distances (JostD) with IBDWS.

We tested four different population genetic scenarios about the directionality of average gene flow patterns among sites with the software MIGRATE-N (Beerli and Palczewski 2010): (1) a model with one population size, where the eight sampled sites are part of the same panmictic population; (2) a model with eight population sizes and symmetric migration rates between each site and the geographically closest site (isolation by geographic distance); (3) an unrestricted full migration model with eight population sizes and 64 symmetrical migration rates among all sites (e.g., from sites A to B and from B to A, etc.); and (4) a model with eight population sizes and 21 asymmetric 
migration rates following the anisotropic larval connectivity suggested by the HAMSOM oceanographic model during summer (Fig. 2c, see "Results" for details). We conducted preliminary runs using model 3 to determine convergence of posterior probabilities for each parameter. We used the Bayesian inference approach, a Brownian motion mutation model, 1,000,000 recorded steps from which the first 25\% was discarded as burn-in, 1 long chain and four heated chains with a static heating scheme, uniform priors, and a tree swapping interval of 10 . We used the ratio of the marginal likelihoods (Bayes factors) to compare and select the model best supported by the genetic data as indicated by the highest natural log Bayes factor with a Bezier approximation (Beerli and Palczewski 2010). We determined convergence across three replicated runs for each model. For the best supported model, we used the posterior distributions of $\Theta\left(4 \mathrm{~N}_{\mathrm{e}} \mu\right)$ and $\mathrm{M}(\mathrm{m} \mu)$ to calculate the number of migrants per generation $(N m)$ as $\Theta \times \mathrm{M} / 4$, where $\Theta$ belongs to the recipient population (Beerli 2009). We estimated the role of each site as either sink or source by subtracting the total $\mathrm{Nm}$ leaving from the $\mathrm{Nm}$ entering each site.

\section{Fig. 2}

Modeled networks of larval connectivity. Spatial networks of larval dispersal between sites (nodes) for a planktonic larval duration of 28 days during winter (a), spring (b), summer (c), and fall (d). Line width is proportional to probability according to the scale within each panel. The direction of larval dispersal is indicated by different colors: northward (red) and southward (blue) (see Online Resource 2 for a video of the density of virtual larvae for each release date) 


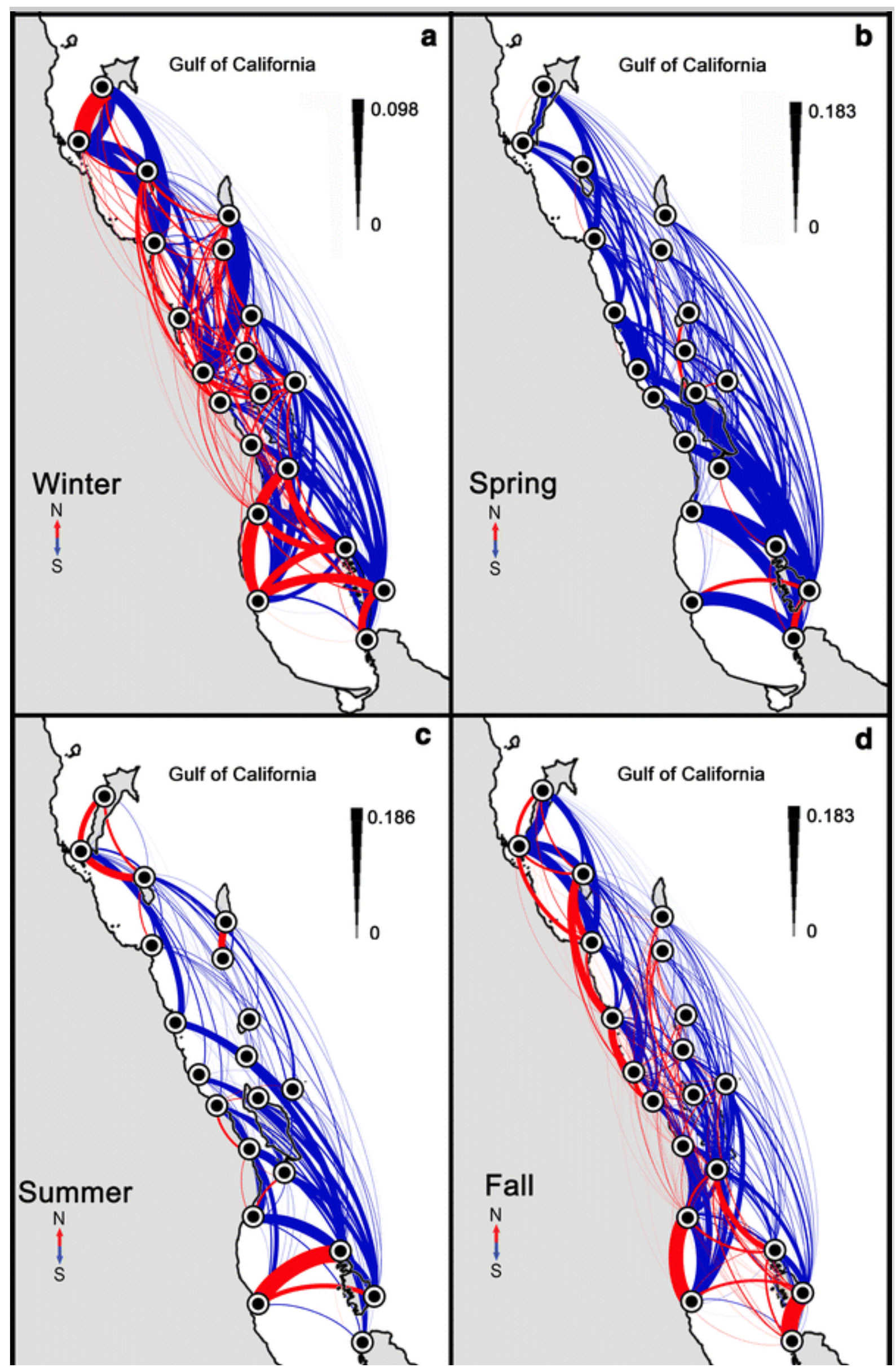




\section{Results}

\section{Oceanographic model}

We simulated a total of 1280,000 virtual $L$. peru larvae (4000 larvae $\times 20$ sites $\times 16$ release dates). All seasonal networks representing patterns of marine connectivity showed all nodes (sites) completely connected via larval dispersal (Fig. 2). Graph size was higher during the cold seasons (fall: 330, winter: 327 ) with less complex networks observed during the warm seasons (spring: 195, summer: 138). As expected, oceanic currents in the GC changed directions drastically twice a year at the beginning of spring and fall (Online Resource 2). The ocean circulation in the study area of the SWGC followed a predominantly anticyclonic (clockwise) circulation during winter that generated connections in both northward and southward directions between coastal sites and main islands (Fig. 2a). The direction of the currents shifted during spring and summer to a predominant cyclonic (anticlockwise) circulation causing a strong current with a predominantly southward direction with only few larval dispersal events towards the north (Fig. 2b, c). The oceanic currents reversed again during fall to the anticyclonic period causing northward and southward connections (Fig. 2d).

The metrics calculated to describe the metapopulation dynamics of each site in the network indicated strong seasonal and latitudinal trends (Fig. 3, Online Resource 3). During spring and summer, in-degree was considerably lower and out-degree higher in the northern half of the study area (sites 1-10), while the opposite was true for the southern section (sites 11-20). During fall and winter, both in-degree and out-degree showed a more even distribution with slightly higher values of in-degree at southern locations. We observed the highest IP values during most of the year (spring-fall) at sites 15-20 located south of San Jose Island, while other sites showing moderate IP values through the year were the island site 3 , and sites along the coast 5, 8, 10, and 13. In contrast, EP peaked at various locations spread along the region through the year, including island sites 1 and 2 and sites along the coasts 5, 8, 10, 13, 14, 16, and 19. Both IP and EP values were comparatively lower during summer. We observed high local larval retention only at three sites that were consistent through the year, including two island sites 1 and 11 and the coastal site 13 . Other sites showing relatively large values of local retention 
included the island site 17 (spring), and the coastal sites 14 (summer) and 10, 16, and 19 (fall). Patterns of eigenvector centrality mirrored those of in-degree.

\section{Fig. 3}

Range of seasonal and annual values for six node-based network metrics calculated from spatial networks among 20 sites after a planktonic larval duration of 28 days: in-degree, out-degree, import probability (Import P), export probability (Export P), probability of local larval retention (Local R), and eigenvector centrality (Eigenvector). The scale shows the percentage relative to the maximum values observed within each metric (see Online Resource 3 for details)

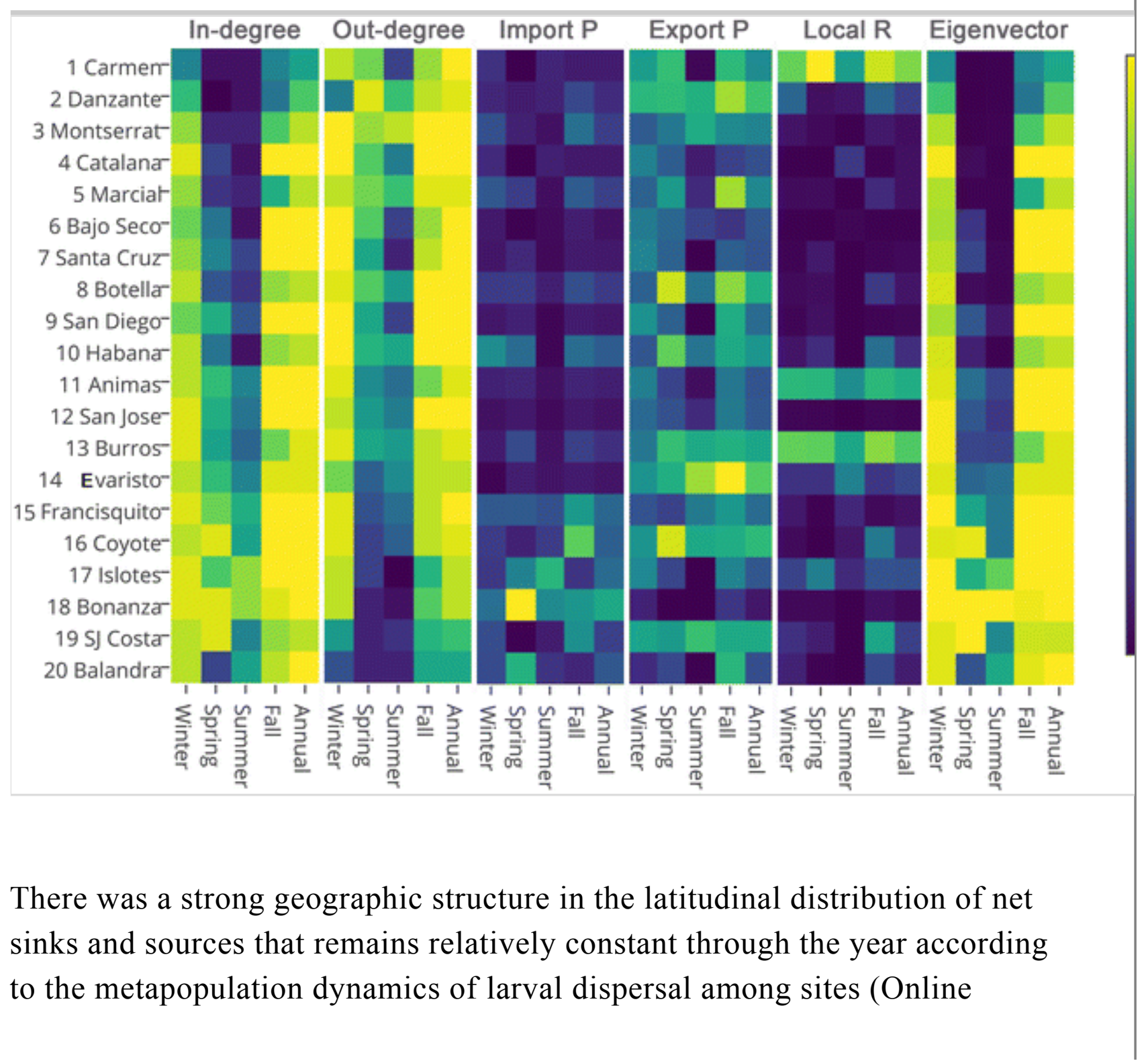


Resource 4). With few exceptions, northern and central sites (1-14) were consistently identified as larval sources in all seasonal networks, while areas south of San Jose Island (sites 15-20) were mainly recognized as larval sinks through the year. The three most important sources of larvae with the largest EP - IP values were the coastal site 14 and the island sites 1 and 2, while the three most important sinks with the lowest EP - IP values were located in the southern section of the study region, including two in Espiritu Santo Island (17 and 18) and one in the coast (20).

\section{Genetic diversity}

We found very high levels of genetic diversity in L. peru (Table 1, Online Resource 5). The number of alleles ranged from 15.8 to 19.9 (average 18.1), the number of effective alleles varied from 10.4 to 13.0 (average 12.0), and rarefied allelic richness ranged from 15.8 to 17.7. Average observed and expected heterozygosities were 0.810 and 0.898 , respectively. The number of private alleles varied from 0.133 to 0.800 , and the private allelic richness ranged from 0.26 to 0.78 . We found no evidence of genotyping errors, null alleles or large allele drop-out. From 120 tests of deviations from HWE performed, 27 combinations of loci/site $(22.5 \%)$ were statistically significant after the FDR test (Adjusted $P=0.016$ ), without any apparent trend within loci or populations. From 105 tests of LD between pairs of loci, 19 (18\%) were significant after FDR (Adjusted $P=0.014$ ). Missing data were present in only $3.08 \%$ of the data set. Therefore, we included all loci and samples in further analyses.

We found that a linear regression model of values of in-degree from the modeled network of larval dispersal during the spring season explained a significant amount of the variance observed in effective alleles within the eight sampled sites $\left(R^{2}=0.558, F_{1,6}=7.575, P=0.033\right.$, Fig. 4 a). Similar analyses were not significant for any the other seasons (winter $R^{2}=0.003$, $F_{1,6}=0.019, P=0.892$; summer $R^{2}=0.296, F_{1,6}=2.530, P=0.162$; and fall $\left.R^{2}=0.270, F_{1,6}=2.229, P=0.186\right)$. Linear regression analyses between the probability of local retention and average genetic relatedness were not significant for any season (winter $R^{2}=0.002, F_{1,6}=0.0154, P=0.905$; spring $R^{2}=0.0, F_{1,6}=0.000, P=0.993$; summer $R^{2}=0.016, F_{1,6}=0.102$, 
$P=0.759$; fall $\left.R^{2}=0.000, F_{1,6}=0.002, P=0.963\right)$. In contrast, a linear regression model between EP and IP for the summer season that described the role of each site as a source or sink was not significant but explained nearly $40 \%$ of the variance observed in average relatedness within each site $\left(R^{2}=0.397, F_{1,6}=3.956, P=0.093\right.$, Fig. $\left.4 \mathrm{~b}\right)$. Results were not significant for any of the other seasons (winter $R^{2}=0.154, F_{1,6}=1.093, P=0.336$; spring $R^{2}=0.044, F_{1,6}=0.279, P=0.616$; fall $\left.R^{2}=0.170, F_{1,6}=1.229, P=0.309\right)$. An analysis of the scatter plot showed that the coastal site 8 , which showed the largest observed relatedness value, could likely represent an outlier. A model excluding site 8 was highly significant for summer $\left(R^{2}=0.800\right.$, $F_{1,5}=20.056, P=0.006$, Fig. $4 \mathrm{~b}$ ), but not for any of the other seasons (winter $R^{2}=0.286, F_{1,5}=2.007, P=0.215$; spring $R^{2}=0.006, F_{1,5}=0.032$, $P=0.865$; fall $\left.R^{2}=0.098, F_{1,5}=0.544, P=0.493\right)$.

\section{Fig. 4}

a Scatter plot showing the relationship between in-degree estimates from the oceanographic model during spring after a planktonic larval duration of 28 days and the effective number of alleles observed within each site $\left(R^{2}=0.558\right.$, $F_{1,6}=7.575, P$ value $\left.=0.033\right)$. b Scatter plot showing the relationship between a metric describing the role of each site as a source or sink (EP - IP), calculated from the oceanographic model during summer after a planktonic larval duration of 28 days, and average genetic relatedness observed within each site $\left(R^{2}=0.397, F_{1,6}=3.956, P=0.093\right)$. The star indicates site 8 , which was considered as a likely outlier (see text for details, $R^{2}=0.800, F_{1,6}=20.056$, $P=0.006$ after excluding site 8 ) 

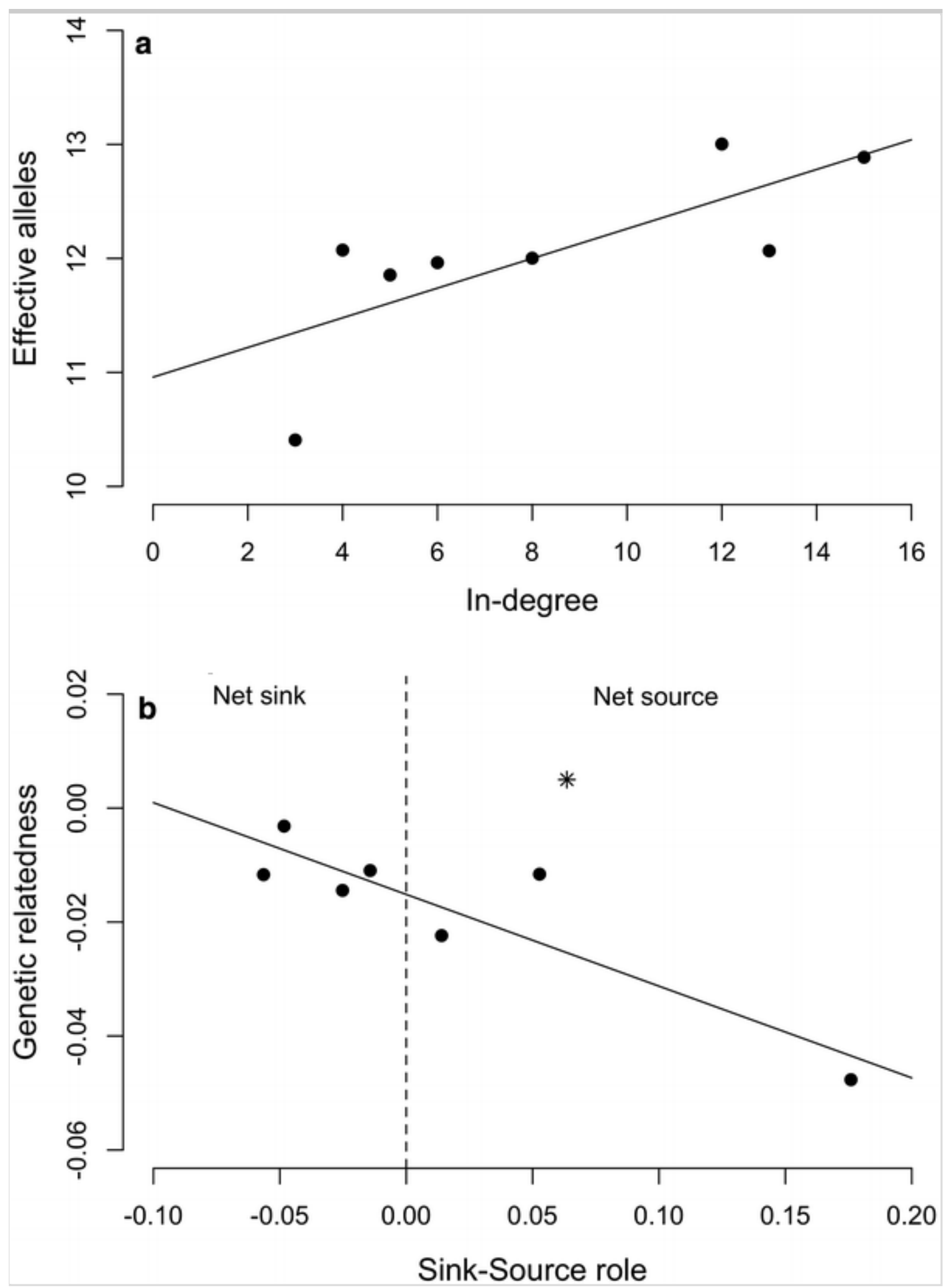

Genetic structure 
The analysis of statistical power indicated the 15 microsatellite loci genotyped had a very high power to detect very low $F_{\mathrm{ST}}$ values. The power for detecting $F_{\mathrm{ST}}=0.003$ or higher was $100 \%$, for $F_{\mathrm{ST}}=0.002$ was $98.7 \%$, and for $F_{\mathrm{ST}}=0.001$ was $87.8 \%$. The hierarchical AMOVA found significant variance among populations $\left(F_{\mathrm{ST}}=0.008,95 \% \mathrm{CI} 0.002-0.011, d f=7\right.$, $P=0.001)$, among individuals $\left(F_{\mathrm{IS}}=0.110,95 \%\right.$ CI $0.083-0.137, d f=217$, $P=0.001)$, and within individuals $\left(F_{\mathrm{IT}}=0.115,95 \%\right.$ CI $0.087-0.143$, $d f=225, P=0.001)$, rejecting the model of panmixia. From 28 pairwise values of genetic distance between sites, 12 comparisons (43\%) were considered statistically significant (Table 2). $F_{\mathrm{ST}}$ values ranged from -0.002 to 0.023 , and JostD values varied from -0.002 to 0.208 . All pairwise $F_{\text {ST }}$ values including site 3 were significant and about half of the $F_{\mathrm{ST}}$ values with the sites 4 and 9 were also significant. These three sites showing the highest level of genetic structures (3, 4, and 9) are small islands located 20-30 km off the coast in the northern and central parts of the study area. The presence of a geographic pattern, where small off-shore islands in the north and center of the study region displayed a significant genetic structure did not support the model of chaotic genetic patchiness. A Mantel test between the logarithm of geographic distances and the logarithm of genetic distances (JostD) was not significant $\left(R^{2}=0.000, F_{1,26}=0.009, P=0.439\right)$, rejecting the model of isolation by geographic distance. In contrast, a Mantel test indicated that the logarithm of oceanographic distances during summer explained a significant amount of the variance observed among the logarithm of the JostD genetic distances between sites $\left(R^{2}=0.311, F_{1,26}=9.950, P=0.004\right.$, Fig. 5).

However, the oceanographic distances from other seasons were not significant predictors of genetic distances (winter $R^{2}=0.0157, F_{1,26}=0.063, P=0.3060$, spring $R^{2}=0.0679, F_{1,26}=2.097, P=0.8280$, fall $R^{2}=0.000, F_{1,26}=0.018$, $P=0.4270$ ). These results supported that the seascape approach informed by an oceanographic model can help to predict observed genetic distances in $L$. peru, but only within one season of the year (summer).

\section{Table 2}

Genetic distance between sites estimated from 15 microsatellite loci in Lutjanus peru

\begin{tabular}{|l|l|l|l|l|l|l|l|l|}
\hline & $\mathbf{3}$ & $\mathbf{4}$ & $\mathbf{5}$ & $\mathbf{6}$ & $\mathbf{8}$ & $\mathbf{9}$ & $\mathbf{1 1}$ & $\mathbf{1 5}$ \\
\hline 3 & 0 & 0.187 & 0.08 & 0.129 & 0.208 & 0.168 & 0.163 & 0.156 \\
\hline
\end{tabular}




\begin{tabular}{|c|c|c|c|c|c|c|c|c|}
\hline & 3 & 4 & 5 & 6 & 8 & 9 & 11 & 15 \\
\hline \multicolumn{9}{|l|}{ Montserrat } \\
\hline 4 Catalana & 0.020 & 0 & 0.044 & 0.059 & 0.067 & 0.068 & 0.031 & 0.049 \\
\hline 5 Marcial & 0.009 & 0.004 & 0 & 0.052 & 0.051 & 0.045 & -0.018 & 0.039 \\
\hline 6 Bajo Seco & 0.014 & 0.005 & 0.005 & 0 & 0.035 & 0.057 & 0.018 & 0.019 \\
\hline 8 Botella & 0.023 & 0.006 & 0.005 & 0.003 & 0 & 0.049 & 0.007 & 0.009 \\
\hline 9 San Diego & 0.018 & 0.006 & 0.004 & 0.005 & 0.004 & 0 & 0.027 & 0.029 \\
\hline 11 Animas & 0.017 & 0.003 & -0.002 & 0.002 & 0.001 & 0.002 & 0 & -0.002 \\
\hline $\begin{array}{l}15 \\
\text { Francisquito }\end{array}$ & 0.016 & 0.004 & 0.003 & 0.002 & 0.001 & 0.002 & 0.000 & 0 \\
\hline \multicolumn{9}{|c|}{$F_{\mathrm{ST}}$ (below diagonal), JostD (above diagonal) } \\
\hline \multicolumn{9}{|c|}{$\begin{array}{l}\text { Significant values are shown in bold after applying a False Discovery Rate } \\
(\alpha=0.05 \text {, corrected } P \text { value }=0.020)\end{array}$} \\
\hline
\end{tabular}

Fig. 5

Scatterplot showing the relationship between the logarithm of the oceanographic distances from the modeled network after a planktonic larval duration of 28 days during summer and the logarithm of the empirical genetic distances (JostD) between sites $\left(R^{2}=0.311, F_{1,26}=9.950, P=0.004\right)$

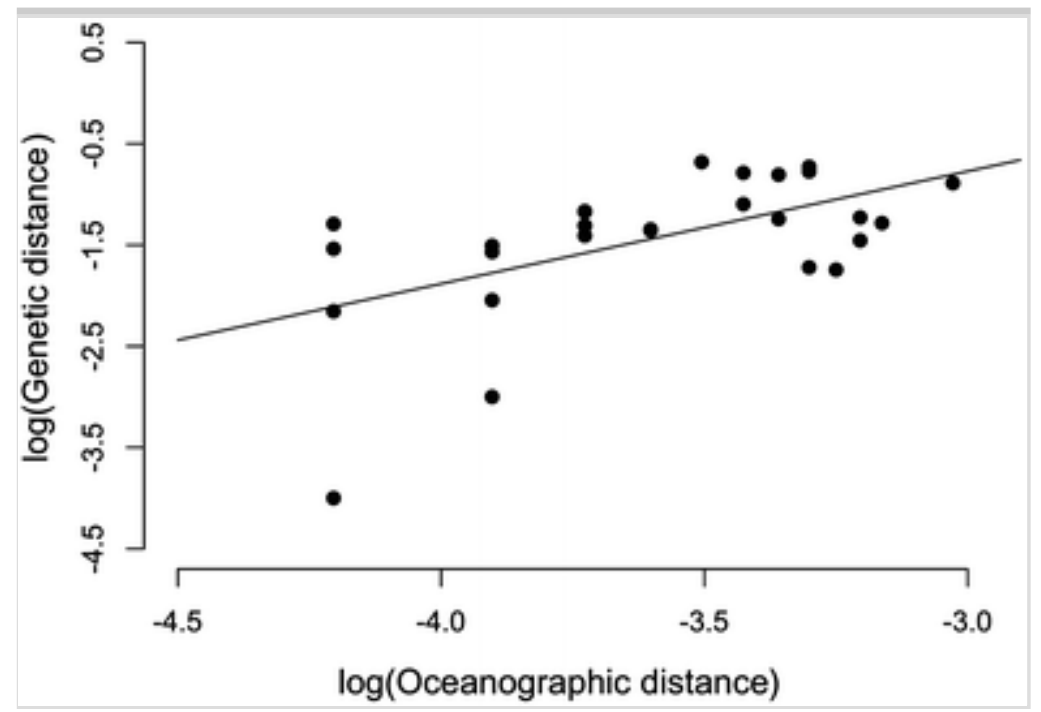


According to the Bayes' factors (Table 3), model 4 representing a scenario of asymmetrical larval migration among sites suggested by the oceanographic model during summer was the best supported migration model. Model 1 representing a panmictic population in the study area scored the lowest. Estimates of $\Theta, \mathrm{M}$, and $\mathrm{Nm}$ for the best supported model are shown in Online Resource 6. Results suggested sources were located mainly in the north of the study area (sites $3,4,5$, and 11 ), while sites in the south predominantly acted like sinks (sites 6, 8, 9, and 15).

\section{Table 3}

Natural log Bayes Factors and log marginal likelihoods for each gene flow model estimated with MIGRATE-N using multilocus genotypes for eight populations and 15 microsatellite markers in Lutjanus peru

\begin{tabular}{|l|l|l|l|}
\hline Model No. & Bezier $\mathbf{~ I m L}$ & Rank & Model probability \\
\hline 1 Panmictic & $-19,870,137.16$ & 4 & 0.000 \\
\hline 2 IBD & $-6,848,848.59$ & 2 & 0.000 \\
\hline 3 Full model & $-7,020,680.79$ & 3 & 0.000 \\
\hline 4 Asymmetric & $-6,616,879.98$ & 1 & 1.000 \\
\hline $\begin{array}{l}\text { The four models tested are: (1) panmictic, (2) isolation by distance (IBD), (3) full } \\
\text { model, and (4) asymmetric (see "Methods" section for details of each model) }\end{array}$
\end{tabular}

\section{Discussion}

We showed that patterns of population genetic structure in L. peru were not consistent with any of three population genetic scenarios commonly used to explain population structure in marine fishes with planktonic larvae.

However, an explicit seascape genetic approach describing metapopulation dynamics via larval dispersal driven by oceanic currents significantly explained observed levels of genetic structure between sites and levels of genetic diversity within sites.

In the absence of unequivocal information about the spawning period of $L$. peru, our approach that contrasted the observed genetic patterns against the 
metapopulation structure informed by the modeled seasonal ocean circulation showed the oceanic currents during spring and summer were the only seasons that explained the empirical genetic data. This result suggests that spring and summer are likely the main seasons when the L. peru samples we analyzed from the SWGC were transported during their larval period by oceanic currents. This novel method of indirectly inferring spawning periods based on the fit between seasonal modeled patterns of larval dispersal and empirical genetic data based on expectations from metapopulation theory could be useful in other species, where information about the reproductive timing and duration is conflicting or currently unavailable. Independent data about records of fishery landings of $L$. peru and the observed abundance of $L$. peru larvae in the GC further support our conclusion that metapopulation structure and larval dispersal in the species follow the spring and summer ocean circulation patterns. For many species of reef fishes that form reproductive aggregations in the GC, peaks in monthly landings and revenues coincide with the timing of spawning aggregations when they become more vulnerable to fishing (Erisman et al. 2010). In the SWGC, landings for L. peru show the highest peak between the start of spring (March) (Erisman et al. 2010) and the end of spring (May), and gradually decrease through the rest of the year (Marquez-Farias and Zamora-Garcia 2016). In addition, long-term studies of the CALCOFI atlas series based on oceanographic cruises in the GC indicate that larvae from $L$. peru have been collected mainly during the summer months (Watson and Brogan 1996). Conflicting observations regarding the spawning seasonality of $L$. peru outside the spring-summer seasons could be explained if spawning takes place during different times at distinct locations within the GC. Asynchronous reproduction of fishes has been reported for few species in the GC, including the yellow snapper (Lutjanus argentiventris) that spawns during summer in the SWGC (Aburto-Oropeza et al. 2009) and during winter in the Southeastern GC (Piñon et al. 2009). The leopard grouper seems to spawn earlier (March-May) in the Southern GC and later (May-June) in the Northern GC (Sala et al. 2003; Munguia-Vega et al. 2014). The strong seasonality in oceanic currents in the GC could translate in contrasting patterns of larval connectivity among populations of the same species that show asynchronous reproduction in different locations.

Contrary to other studies (Teske et al. 2016), our analyses showed that the 
average genetic relatedness among individuals from $L$. peru within each site was not correlated with the probability of local retention predicted by the oceanographic model. However, we found some support to the hypothesis that the relatedness of individuals within each site depends on the balance between the amount of larvae that is imported and exported. Net sinks that received more larvae than they exported showed higher levels of relatedness than net sources. This result suggests that local population dynamics in strongly advective systems like the GC could be more influenced by the role of the site as net sink or source within the metapopulation (i.e., external influences) and less by the process of local larval retention itself (Hedgecock 2010). Alternatively, our oceanographic model could lack the coastal resolution needed to realistically track self-retention of larvae (Nickols et al. 2015), or our passive larval dispersal model could misrepresent patterns of local larval retention that are influenced by larval behavior (Leis et al. 2014; Irisson et al. 2015). The coastal site 8 (Botella), identified as a likely outlier, actually showed the highest average relatedness value among the eight sites analyzed, suggesting a lower fit between the oceanographic model and instances of extreme values in the empirical genetic data. The discrepancy between the oceanographic model that suggested site 8 was a source and the empirical genetic data that indicated it was likely the strongest sink with the highest levels of relatedness could be explained if, for example, this site shows high levels of local retention not predicted by the model. The estimate in the number of migrants $(\mathrm{Nm})$ entering and leaving site 8 according the best supported population genetic scenario indicated its role as a net sink (Online resource 6), suggesting that the model overestimated the amount of actual larval export and/or underestimated the amount of larval input. Another feasible scenario is the presence of unsampled "ghost" populations that could be supplying larvae to site 8 . These observations highlight that oceanographic models could be further improved on realistic spatial and temporal scales based on mismatches with empirical data (Metaxas and Saunders 2009).

Our results corroborated that in the $\mathrm{GC}$, the geographic distance between sites is a poor predictor of larval connectivity for species with planktonic larvae compared to oceanographic distances that follow the direction and consider the strength of the predominant currents during the spawning period (Munguia-Vega et al. 2014; Lodeiros et al. 2016). The strong asymmetry in 
the direction of oceanic currents in the GC causes that larval connectivity between sites is anisotropic or that shows different values when measured in different directions. An example of this anisotropy on connectivity is the relatively lower connectivity found between off-shore small islands in our study area and relatively nearby coastal sites located $20-30 \mathrm{~km}$ to the west due to the presence of a predominant southward current during the spawning period. This property of the anisotropic larval connectivity in the GC contrasts with the previous observations elsewhere, where larval connectivity is assumed to be a function of geographic distance as measured in all directions (Almany et al. 2009; D’Aloia et al. 2015; Green et al. 2015). According to theory and simulations, the genetic consequences of asymmetric dispersal as many parallels with a scenario of collective dispersal since both processes increase the probability of sampling individuals from the same natal population and the rate of genetic drift (Eldon et al. 2016). The result is an increase in population differentiation despite high migration rates, in contrast to the classical role of migration during symmetric dispersal (Yearsley et al. 2013). Most empirical studies regarding asymmetric dispersal involve aquatic species and have focused on the contribution of upstream sites to the genetic diversity of downstream populations (Pringle et al. 2011: Paz-Vinas et al. 2015). The roles of anisotropic dispersal, collective dispersal, variation in individual reproductive success, and asynchronous local population dynamics on the presence of seemingly chaotic genetic patchiness are at the core of the research needed to understand the evolution of marine species with planktonic larvae.

A pattern of anisotropic larval connectivity has strong implications for management and conservation of marine resources. For example, recommendations for spacing of marine reserves for L. peru in the GC should be based on oceanographic distances that explicitly incorporate the direction and intensity of currents during the spawning period. Consequently, sites that might appear distant from each other (e.g., separated by geographic distances of 50-80 km in our study) could show short oceanographic distances and high rates of larval exchange when considering oceanic currents in the relevant directions and seasons. Consequently, recommendations for marine reserve spacing in the GC should explicitly consider the PLD and the direction of the currents during the spawning period of the target species, instead of applying 
rules of thumb that assume that larval connectivity decreases as a function of geographic distance in all directions (i.e., isotropy) during any time of the year. Likewise, under strong asymmetric currents within a defined spatial domain (Fig. 1), marine reserves located upstream (e.g., sites 1-6 in our study) could be more effective, since they will export L. peru larvae to multiple downstream sites (i.e., higher out-degree), creating a domino effect of larval export to other reserves and fishing sites (Green et al. 2014; Munguia-Vega et al. 2014). In contrast, marine reserves located downstream (e.g., 16-20) will have little or no effect in terms of larval export to the rest of the network (i.e., lower out-degree).

The modeling we conducted is a first step towards understanding metapopulation structure of L. peru in the GC, but can be improved in several aspects. First, we assumed that larvae were passively advected, and various studies suggest that the late stages of fish larvae could have significant sensory and swimming abilities that could reduce the influence of oceanic currents on dispersal (Leis et al. 2014; Irisson et al. 2015). Our models implicitly assumed that larval production, larval survival, and the amount of recruitment habitat for L. peru were homogeneous across the study region, while is recognized that these aspects are key in shaping the realized patterns of larval connectivity (Cowen and Sponaugle 2009; Burgess et al. 2012). The oceanographic model and the genetic sampling we conducted did not include temporal replicates or the effects of ENSO events, a step needed to disentangle the effects of inter-annual variation of oceanic currents and temporal shifts in local population dynamics. In addition, we did not explicitly consider the movement of adult fish within their home range or as part of spawning migrations, neither we considered ontogenetic shifts between distinct recruitment habitat for juveniles and adults, and both aspects are likely to influence the observed patterns of genetic connectivity among sites (Green et al. 2015). Although no information is currently available on any of these aspects for L. peru, such information could improve the explanatory power of our models when it becomes available.

\section{Acknowledgements}

We would like to acknowledge Juan Leonardo Lucero Cuevas (Tito), Aaron León, Jose Amador Gutierrez (Pepe), Amairany León, Mariely Alvarez, Jaime 
de la Toba and Joel Castro for their assistance with acquiring samples in the field. Mariana Walther helped with logistics during the early stage of the project. Geraldine Parra, Alexander Ochoa, Karla Vargas, Jose Francisco Dominguez-Contreras (Borre), and Stacy L. Sotak helped us at various stages during microsatellite genotyping. DAPG received a CONACYT fellowship (250126). This work was funded by The Walton Family Foundation Grant \# 2011-1235, The David and Lucile Packard Foundation Grants \#2013-39359, \#2013-39400, and \#2015-62798, and Fondo Institucional CONACYT-

Fronteras de la Ciencia (Project 26/2016).

Compliance with ethical standards

Ethical approval All applicable international, national, and/or institutional guidelines for the care and use of animals were followed. Necessary permits were obtained prior to conducting the research.

Conflict of interest All authors declare that they have no conflict of interest.

\section{Electronic supplementary material}

Below is the link to the electronic supplementary material.

Supplementary material 1 (M4V $1558 \mathrm{~kb})$

Supplementary material 2 (PDF $6114 \mathrm{~kb}$ )

\section{References}

Aburto-Oropeza O, Dominguez-Guerrero I, Cota-Nieto J, Plomozo-Lugo T (2009) Recruitment and ontogenetic habitat shifts of the yellow snapper (Lutjanus argentiventris) in the Gulf of California. Mar Biol 156:2461-2472. https://doi.org/10.1007/s00227-009-1271-5

Almany GR, Connolly SR, Heath DD, Hogan JD, Jones GP, McCook LJ, 
Mills M, Pressey RL, Williamson DH (2009) Connectivity, biodiversity conservation and the design of marine reserve networks for coral reefs. Coral Reefs 28:339-351. https://doi.org/10.1007/s00338-009-0484-X

Almany GR, Planes S, Thorrold SR, Berumen ML, Bode M, SaenzAgudelo P, Bonin MC, Frisch AJ, Harrison HB, Messmer V, Nanninga GB, Priest MA, Srinivasan M, Sinclair-Taylor T, Williamson DH, Jones JP (2017) Larval fish dispersal in a coral-reef seascape. Nat Ecol Evol 1:0148. https://doi.org/10.1038/s41559-017-0148

Amos W, Hoffman JI, Frodsham A, Zhang L, Best S, Hill AVS (2007) Automated binning of microsatellite alleles: problems and solutions. Mol Ecol Notes 7:10-14. https://doi.org/10.1111/j.1471-8286.2006.01560.x

Backhaus JO (1985) A three-dimensional model for the simulation of the shelf sea dynamics. Dtsch Hydrogr 38:165-187

Barbosa-Ortega WA, Rivera-Camacho AR, Avila-Poveda OH, CeballosVázquez BP, Arellano-Martínez M (2015) Biología reproductiva de Lutjanus peru y Lutjanus argentiventris (Perciformes: Lutjanidae) en la costa sur-occidental del Golfo de California. IPN-CICIMAR., La Paz, B.C.S

Bastian M, Heymann S, Jacomy M (2009) Gephi: an open source software for exploring and manipulating networks. International AAAI Conference on Weblogs and Social Media

AQ4

Beerli P (2009) How to use migrate o why are markov chain Monte Carlo programs difficult to use? In: Bertorelle G, Bruford MW, Hauffe HC, Rizzoli A, Vernesi C (eds) Population genetics for animal conservation. Cambridge University Press, Cambridge, pp 42-79

Beerli P, Palczewski M (2010) Unified framework to evaluate panmixia and migration direction among multiple sampling locations. Genetics 185:313-326. https://doi.org/10.1534/genetics.109.112532 
Beldade R, Jackson AM, Cudney-Bueno R, Raimondi PT, Bernardi G (2014) Genetic structure among spawning aggregations of the gulf coney Hyporthodus acanthistius. Marine Ecol Prog Ser 499:193-201. https://doi.org/10.3354/meps 10637

Benjamini BY, Yekutieli D (2001) The control of the false discovery rate in multiple testing under dependency. Ann Stat 29:1165-1188

Burgess SC, Treml EA, Marshall DJ (2012) How do dispersal costs and habitat selection influence realized population connectivity? Ecol 93:1378-1387. https://doi.org/10.1890/11-1656.1

Burgess SC, Nickols KJ, Griesemer CD, Barnett LAK, Dedrick AG, Satterthwaite EV, Yamane L, Morgan SG, White JW, Botsford LW (2014) Beyond connectivity: how empirical methods can quantify population persistence to improve marine protected area design. Ecol Appl 24:257-270. https://doi.org/10.1890/13-0710.1

Christie MR, Johnson DW, Stallings CD, Hixon MA (2010)

Self-recruitment and sweepstakes reproduction amid extensive gene flow in a coral-reef fish. Mol Ecol 19:1042-1057. https://doi.org/10.1111 /j.1365-294X.2010.04524.x

Cowen RK, Sponaugle S (2009) Larval dispersal and marine population connectivity. Annu Rev Mar Sci 1:443-466. https://doi.org/10.1146 /annurev.marine.010908.163757

Cowen RK, Lwiza KMM, Sponaugle S, Paris BC, Olson DB (2000) Connectivity of marine populations: open or closed? Science 287:857-859. https://doi.org/10.1126/science.287.5454.857

D’Aloia CC, Bogdanowicz SM, Francis RK, Majoris JE, Harrison RG, Buston PM (2015) Patterns, causes, and consequences of marine larval dispersal. Proc Natl Acad Sci USA 112:13940-13945. https://doi.org /10.1073/pnas. 1513754112 
Diaz-Uribe JG, Chavez EA, Elorduy-Garay JF (2004) Assessment of the Pacific red snapper (Lutjanus peru) fishery in the southwestern Gulf of California. Cienc Mar 30:561-574

Dubois M, Rossi V, Ser-Giacomi E, Arnaud-Haond S, López C, Hernández-García E (2016) Linking basin-scale connectivity, oceanography and population dynamics for the conservation and management of marine ecosystems. Glob Ecol Biogeogr 25:503-515. https://doi.org/10.1111/geb.12431

Dyer RJ (2009) GeneticStudio: a suite of programs for spatial analysis of genetic-marker data. Mol Ecol Resour 9:110-113. https://doi.org/10.1111 /j.1755-0998.2008.02384.x

Dyer RJ (2015) Population graphs and landscape genetics. Annu Rev Ecol Syst 46:327-342. https://doi.org/10.1146/annurev-ecolsys-112414-054150

Eldon B, Riquet F, Yearsley J, Jollivet D, Broquet T (2016) Current hypotheses to explain genetic chaos under the sea. Curr Zool 62:551-566. https://doi.org/10.1093/cz/zow094

Erisman B, Mascarenas I, Paredes G, Sadovy de Mitcheson Y, AburtoOropeza O, Hastings P (2010) Seasonal, annual, and long-term trends in commercial fisheries for aggregating reef fishes in the Gulf of California, Mexico. Fish Res 106:279-288. https://doi.org/10.1016 /j.fishres.2010.08.007

Galindo HM, Olson DB, Palumbi SR (2006) Seascape genetics: a coupled oceanographic-genetic model predicts population structure of Caribbean corals. Curr Biol 16:1622-1626. https://doi.org/10.1016/j.cub.2006.06.052

Green AL, Fernandes L, Almany G, Abesamis R, McLeod E, Aliño PM, White AT, Salm RV, Tanzer J, Pressey RL (2014) Designing marine reserves for fisheries management, biodiversity conservation, and climate change adaptation. Coast Manag 42:143-159. https://doi.org/10.1080 /08920753.2014.877763 
Green AL, Maypa AP, Almany GR, Rhodes KL, Weeks R, Abesamis RA, Gleason MG, Mumby PJ, White AT (2015) Larval dispersal and movement patterns of coral reef fishes, and implications for marine reserve network design. Biol Rev Camb Philos Soc 90:1215-1247. https://doi.org/10.1111 /brv.12155

Hedgecock D (2010) Determining parentage and relatedness from genetic markers sheds light on patterns of marine larval dispersal. Mol Ecol 19:845-847. https://doi.org/10.1111/j.1365-294X.2010.04525.x

Hedgecock D, Pudovkin AI (2011) Sweepstakes reproductive success in highly fecund marine fish and shellfish: a review and commentary. Bull Mar Sci 87:971-1002. https://doi.org/10.5343/bms.2010.1051

Hedgecock D, Barber PH, Edmands S (2007) Genetic approaches to measuring connectivity. Oceanography 20:70-79

Iacchei M, Ben-Horin T, Selkoe KA, Bird CE, Garcia-Rodriguez FJ, Toonen RJ (2013) Combined analyses of kinship and FST suggest potential drivers of chaotic genetic patchiness in high gene-flow populations. Mol Ecol 22:3476-3494. https://doi.org/10.1111/mec.12341

Irisson JO, Paris CB, Leis JM, Yerman MN (2015) With a little help from my friends: group orientation by larvae of a coral reef fish. PLoS One 10:e0144060. https://doi.org/10.1371/journal.pone.0144060

Jensen JL, Bohonak AJ, Kelley ST (2005) Isolation by distance, web service. BMC Genet 6:13. https://doi.org/10.1186/1471-2156-6-13

Johnson MS, Black R (1982) Chaotic genetic patchiness in an intertidal limpet, Siphonaria sp. Mar Biol 70:157-164

Johnson MS, Black R (1984) Pattern beneath the chaos: the effect of recruitment on genetic patchiness in an intertidal limpet. Evolution 38:1371-1383 
Jones GP, Planes S, Thorrold SR (2005) Coral reef fish larvae settle close to home. Curr Biol 15:1314-1318. https://doi.org/10.1016 /j.cub.2005.06.061

Jost L (2008) Gst and its relatives do not measure differentiation. Mol Ecol 17:4015-4026. https://doi.org/10.1111/j.1365-294X.2008.03887.x

Kalinowski ST (2005) HP-rare 1.0: a computer program for performing rarefaction on measures of allelic richness. Mol Ecol Notes 5:187-189. https://doi.org/10.1111/j.1471-8286.2004.00845.x

Kool JT, Paris CB, Barber PH, Cowen RK (2011) Connectivity and the development of population genetic structure in Indo-West Pacific coral reef communities. Glob Ecol Biogeogr 20:695-706. https://doi.org/10.1111 /j.1466-8238.2010.00637.x

Leis JM, Paris CB, Irisson JO, Yerman MN, Siebeck UE (2014) Orientation of fish larvae in situ is consistent among locations, years and methods, but varies with time of day. Mar Ecol Prog Ser 505:193-208. https://doi.org/10.3354/meps 10792

Lodeiros C, Soria G, Valentich-Scott P, Munguía-Vega A, Cabrera JS, Cudney-Bueno R, Loor A, Márquez A, Sonnenholzner S (2016) Spondylids of Eastern Pacific Ocean. J Shellfish Res 35:279-293. https://doi.org/10.2983/035.035.0203

Luiz OJ, Allen AP, Robertson DR, Floeter SR, Kulbicki M, Vigliola L, Becheler R, Madin JS (2013) Adult and larval traits as determinants of geographic range size among tropical reef fishes. Proc Natl Acad Sci USA 110:16498-16502. https://doi.org/10.1073/pnas.1304074110

Marinone SG (2003) A three-dimensional model of the mean and seasonal circulation of the Gulf of California. J Geophys Res 108:1-27. https://doi.org/10.1029/2002jc001720

Marinone SG (2006) A numerical simulation of the two- and three- 
dimensional Lagrangian circulation in the northern Gulf of California. Estuar Coast Shelf Sci 68:93-100. https://doi.org/10.1016 /j.ecss.2006.01.012

Marinone SG (2008) On the three-dimensional numerical modeling of the deep circulation around Ángel de la Guarda Island in the Gulf of California. Estuar Coast Shelf Sci 80:430-434. https://doi.org/10.1016 /j.ecss.2008.09.002

Marinone SG (2012) Seasonal surface connectivity in the Gulf of California. Estuar Coast Shelf Sci 100:133-141. https://doi.org/10.1016 /j.ecss.2012.01.003

Marinone SG, Ulloa M, Paressierra A, Lavin M, Cudneybueno R (2008) Connectivity in the northern Gulf of California from particle trackingin a three-dimensional numerical model. J Mar Syst 71:149-158. https://doi.org /10.1016/j.jmarsys.2007.06.005

Marinone SG, Gonzalez J, Figueroa J (2009) Prediction of currents and sea surface elevation in the Gulf of California from tidal to seasonal scales. Env Model Softw 24:140-143. https://doi.org/10.1016 /j.envsoft.2008.05.003

Marinone SG, Lavín MF, Parés-Sierra A (2011) A quantitative characterization of the seasonal Lagrangian circulation of the Gulf of California from a three-dimensional numerical model. Cont Shelf Res 31:1420-1426. https://doi.org/10.1016/j.csr.2011.05.014

Marquez-Farias F, Zamora-Garcia OG (2016) Informe tecnico del analisis pesquero del corredor San Cosme-Punta Coyote, Baja California Sur, en el periodo 2011-2016. Sociedad de Historia Natural NIPARAJA A.C

Meirmans PG, Van Tienderen PH (2004) Genotype and genodive: two programs for the analysis of genetic diversity of asexual organisms. Mol Ecol Notes 4:792-794. https://doi.org/10.1111/j.1471-8286.2004.00770.x 
Metaxas A, Saunders M (2009) Quantifying the "bio-" components in biophysical models of larval transport in marine benthic invertebrates: advances and pitfalls. Biol Bull 216:257-272. https://doi.org/10.1086 /BBLv216n3p257

Munguia-Vega A, Jackson A, Marinone SG, Erisman B, Moreno-Baez M, Giron A, Pfister T, Aburto-Oropeza O, Torre J (2014) Asymmetric connectivity of spawning aggregations of a commercially important marine fish using a multidisciplinary approach. PeerJ 2:e511. https://doi.org $/ 10.7717 /$ peerj. 511

Munguia-Vega A, Leyva-Valencia I, Lluch-Cota DB, Cruz-Hernández P (2015) Genetic structure of cortes geoduck clam Panopea globosa Dall 1898 from the Mexican Northwest. J Shellfish Res 34:153-161. https://doi.org/10.2983/035.034.0100

Newman MEJ (2003) The structure and function of complex networks. SIAM Rev 45:167-256

Nichols JT, Murphy RC (1922) On a collection of marine fishes from Peru. Bull Amer Mus Nat Hist 46:501-506

Nickols KJ, White JW, Largier JL, Gaylord B (2015) Marine population connectivity: reconciling large-scale dispersal and high self-retention. Am Nat 185:196-211. https://doi.org/10.1086/679503

Ottmann D, Grorud-Colvert K, Sard NM, Huntington BE, Banks MA, Sponaugle S (2016) Long-term aggregation of larval fish siblings during dispersal along an open coast. Proc Natl Acad Sci USA. https://doi.org /10.5061/dryad.b7m47

Pascual M, Rives B, Schunter C, Macpherson E (2017) Impact of life history traits on gene flow: a multispecies systematic review across oceanographic barriers in the Mediterranean Sea. PLoS One 12:e0176419. https://doi.org/10.1371/journal.pone.0176419 
Paz-García DA, Munguía-Vega A, Plomozo-Lugo T, Weaver AH (2017)

Characterization of 32 microsatellite loci for the Pacific red snapper, Lutjanus peru, through next generation sequencing. Mol Biol Rep 44:251-256. https://doi.org/10.1007/s11033-017-4105-4

Paz-Vinas I, Loot G, Stevens VM, Blanchet S (2015) Evolutionary processes driving spatial patterns of intra-specific genetic diversity in river ecosystems. Mol Ecol 24:4586-4604. https://doi.org/10.1111/mec.13345

Peakall R, Smouse PE (2012) GenAlEx 6.5: genetic analysis in Excel. Population genetic software for teaching and research - an update. Bioinform 28:2537-2539. https://doi.org/10.1093/bioinformatics/bts460

Piñon A, Amezcua F, Duncan N (2009) Reproductive cycle of female yellow snapper Lutjanus argentiventris (Pisces, Actinopterygii, Lutjanidae) in the SW Gulf of California: gonadic stages, spawning seasonality and length at sexual maturity. J Appl Icht 25:18-25. https://doi.org/10.1111/j.1439-0426.2008.01178.x

Pringle JM, Blakeslee AMH, Byers JE, Roman J (2011) Asymmetric dispersal allows an upstream region to control population structure throughout a species' range. Proc Natl Acad Sci USA 108:15288-15293. https://doi.org/10.1073/pnas.1100473108

Proehl JA, Lynch DR, McGillicuddy DJ, Ledwell JR (2005) Modeling turbulent dispersion on the North Flank of Georges Bank using Lagrangian Particle Methods. Cont Shelf Res 25:875-900. https://doi.org/10.1016 /j.csr.2004.09.022

Queller DC, Goodnight KF (1989) Estimating relatedness using genetic markers. Evolution 43:258-275

Raymond M, Rousset F (1995) GENEPOP (version 1.2): population genetics software for exact tests and ecumenicism. J Hered 86:248-249

R-Core-Team (2017) R: a language and environment for statistical 
computing. R Foundation for Statistical Computing, Vienna, Austria. http://www.R-project.org/

AQ5

Rocha-Olivares A, Sandoval-Castillo J (2003) Mitochondrial diversity and genetic structure in allopatric populations of the Pacific red snapper Lutjanus peru. Cienc Mar 29:197-209

Ryman N, Palm S (2006) POWSIM: a computer program for assessing statistical power when testing for genetic differentiation. Mol Ecol 6:600-602. https://doi.org/10.1111/j.1365-294X.2006.01378.x

Sala E, Aburto-Oropeza O, Paredes G, Parra I, Barrera JC, Dayton PK (2002) A general model for designing networks of marine reserves. Science 298:1991-1993. https://doi.org/10.1126/science.1075284

Sala E, Aburto-Oropeza O, Paredes G, Thompson G (2003) Spawning aggregations and reproductive behavior of reef fishes in the Gulf of California. Bull Mar Sci 72:103-121

Sale PF, Hanski I, Kritzer JP (2006) The merging of metapopulation theory and marine ecology: establishing the historical context. In: Kritzer JP, Sale PF (eds) Marine metapopulations. Elsevier, Amsterdam, pp 3-28

Selkoe KA, Watson JR, White C, Horin TB, Iacchei M, Mitarai S, Siegel DA, Gaines SD, Toonen RJ (2010) Taking the chaos out of genetic patchiness: seascape genetics reveals ecological and oceanographic drivers of genetic patterns in three temperate reef species. Mol Ecol 19:3708-3726. https://doi.org/10.1111/j.1365-294X.2010.04658.x

Selkoe KA, Gaggiotti OE, Bowen BW, Toonen RJ (2014) Emergent patterns of population genetic structure for a coral reef community. Mol Ecol 23:3064-3079. https://doi.org/10.1111/mec.12804

Selkoe KA, D'Aloia CC, Crandall ED, Iacchei M, Liggins L, Puritz JB, von der Heyden S, Toonen RJ (2016) A decade of seascape genetics: 
contributions to basic and applied marine connectivity. Mar Ecol Prog Ser 554:1-19. https://doi.org/10.3354/meps11792

Soria G, Munguía-Vega A, Marinone SG, Moreno-Báez M, Martínez-Tovar I, Cudney-Bueno R (2012) Linking bio-oceanography and population genetics to assess larval connectivity. Mar Ecol Prog Ser 463:159-175. https://doi.org/10.3354/meps09866

Soria G, Torre-Cosio J, Munguia-Vega A, Marinone SG, Lavín MF, Cinti A, Moreno-Báez M (2014) Dynamic connectivity patterns from an insular marine protected area in the Gulf of California. J Mar Syst 129:248-258. https://doi.org/10.1016/j.jmarsys.2013.06.012

Spalding MD, Fox HE, Allen GR, Davidson N, Ferdaña ZA, Finlayson M, Halpern BS, Jorge MA, Lombana A, Lourie SA, Martin KD, McManus E, Molnar J, Recchia CA, Roberston J (2007) Marine ecoregions of the world: a bioregionalization of coastal and shelf areas. Bioscience $57: 573-583$

Teske PR, Sandoval-Castillo J, van Sebille E, Waters J, Beheregaray LB (2015) On-shelf larval retention limits population connectivity in a coastal broadcast spawner. Mar Ecol Prog Ser 532:1-12. https://doi.org/10.3354 /meps 11362

Teske PR, Sandoval-Castillo J, van Sebille E, Waters J, Beheregaray LB (2016) Oceanography promotes self-recruitment in a planktonic larval disperser. Sci Rep 6:34205. https://doi.org/10.1038/srep34205

Treml EA, Halpin PN, Urban DL, Pratson LF (2008) Modeling population connectivity by ocean currents, a graph-theoretic approach for marine conservation. Landsc Ecol 23:19-36. https://doi.org/10.1007 /s10980-007-9138-y

Treml EA, Roberts JJ, Chao Y, Halpin PN, Possingham HP, Riginos C (2012) Reproductive output and duration of the pelagic larval stage determine seascape-wide connectivity of marine populations. Integr Comp 
Biol 52:525-537. https://doi.org/10.1093/icb/ics101

Van Oosterhout C, Hutchinson WF, Wills DPM, Shipley P (2004) MICROCHECKER: software for identifying and correcting genotyping errors in microsatellite data. Mol Ecol Notes 4:535-538. https://doi.org/10.1111 /j.1471-8286.2004.00684.x

Visser AW (1997) Using random walk models to simulate the vertical distribution of particles in a turbulent water column. Mar Ecol Prog Ser 158:275-281

Watson W, Brogan MW (1996) The early stages of fishes in the California Current Region, Rhodes, MA

Watson JR, Mitarai S, Siegel DA, Caselle JE, Dong C, McWilliams JC (2010) Realized and potential larval connectivity in the Southern California Bight. Mar Ecol Prog Ser 401:31-48. https://doi.org/10.3354 /meps08376

Watson JR, Siegel DA, Kendall BE, Mitarai S, Rassweiller A, Gaines SD (2011) Identifying critical regions in small-world marine metapopulations. Proc Natl Acad Sci USA 108:E907-E913. https://doi.org/10.1073 /pnas. 1111461108

Yearsley JM, Viard F, Broquet T (2013) The effect of collective dispersal on the genetic structure of a subdivided population. Evolution 67:1649-1659. https://doi.org/10.1111/evo.12111

Zarate-Becerra ME, Espino-Barr E, Garcia-Boa A et al (2014) Huachinango del Pacífico Centro-Sur, costa de Nayarit a Chiapas. In: Belendez-Moreno FJ, Espino-Barr E, Galindo-Cortes G, Gaspar-Dillanes MT, Huidobro-Campos L, Morales-Bojorquez E (eds) Sustentabilidad y Pesca Responsable en Mexico Evaluacion y Manejo. SAGARPA Instituto Nacional de Pesca, Mexico, D.F., pp 141-175 